\title{
A questão da cultura popular: as políticas culturais do Centro Popular de Cultura (CPC) da União Nacional dos Estudantes (UNE) ${ }^{1}$
}

\author{
Miliandre Garcia \\ Doutoranda em História — UFRJ
}

RESUMO

Na década de 1980, sobretudo, a literatura que procurou revisar a produção artístico-cultural do CPC caracterizou-a, em linhas gerais, como dogmática e simplista. Com isso, as vozes dissonantes que compunham as esquerdas no período de 1961 a 1964 e que discutiram exaustivamente o engajamento artístico, a cultura popular e a função social da arte foram associadas às formulações genéricas do "manifesto do CPC" (redigido por Carlos Estevam Martins) ou reduzidas à relação intrínseca entre nacionalismo e populismo (enfatizada por Francisco Corrêa Weffort e Octávio Ianni, entre outros). Não obstante, o debate travado no período anterior ao golpe militar evidencia uma diversidade e uma variedade de posturas e posições acerca da arte engajada que só tem a acrescentar à história já contada.

Palavras-chave: CPC; arte; engajamento e políticas culturais.

\section{ABSTRACT}

In 1980's, the literature that tried to revise the artistic-cultural production of the $\mathrm{CPC}$ characterized it, in general lines, as dogmatic and simplistic. With this, the dissonant voices that composed the lefts in the period 1961-1964 and that had argued the artistic enrollment exhaustingly, the popular culture and social function of art were associated to the generic formularizations of the "manifesto do CPC" (written by Carlos Estevam Martins) or reduced to intrinsic relation between nationalism and populism (emphasized by Francisco Corrêa Weffort and Octávio Ianni, among others). However, the debate in the previous period to the military blow evidences a diversity and a variety of positions concerning engaged art which contributes to wat we already know.

Keywords: CPC; Art; Engagement and cultural politics. 


\section{DisPutas estéticas do ARENA AO CPC}

Em geral, tanto o debate quanto a produção artístico-cultural vinculada às diretrizes estéticas e ideológicas do CPC da UNE foram indistintamente caracterizados como dogmáticos e panfletários, ora reflexo do "manifesto do CPC", ora produto da articulação entre populismo e nacionalismo. No entanto, alguns pesquisadores ${ }^{2}$ têm apresentado novas abordagens sobre o tema, na medida em que não priorizam aquele "manifesto do CPC" como tradução direta da arte engajada. O que se coloca com base nessas pesquisas é que para avançar a discussão acerca da produção artística do CPC é preciso romper com a perspectiva analítica que generalizou unilateralmente as relações entre o documento escrito e a produção artística da época, como se o diálogo entre um e outra fosse conseqüência imediata e reflexiva.

A leitura monolítica da produção do CPC decorre muitas vezes das análises circunstanciadas da década de 1980 no interior das ciências sociais em geral. Tomadas como uma ramificação da relação entre o populismo e o nacionalismo, as acepções de Octávio Ianni e Francisco Corrêa Weffort conquistaram o apreço intelectual de um número expressivo de pesquisadores e críticos. $^{3}$

As motivações desses dois autores foram concernentes às motivações das análises que predominaram nos anos 80 , pois ambos inserem-se no quadro de "revisionismo" das atividades e estratégias do Partido Comunista Brasileiro - PCB, seja em decorrência do golpe militar, seja por ocasião do processo de redemocratização da sociedade brasileira e, conseqüentemente, pela emergência do pluripartidarismo político no Brasil. Portanto, qualquer atitude interpretada por esses autores como resquício de uma suposta inércia do PCB em particular e da esquerda em geral, diante das mudanças estruturais da sociedade, foi questionada. E as revisões, sobretudo as dos anos 80 , pautaramse por essa necessidade de revisar o passado político da história recente do Brasil. Foi quando o CPC, vinculado ideologicamente ao PCB e ao Instituto de Estudos Superiores - ISEB, passou a ser alvo - no campo da cultura e da política - de inúmeras críticas relacionadas à opção adotada por seus ativistas. E é nesse processo de transformação pelo qual passou a sociedade brasileira que os debates, as divergências e as contradições internas do CPC foram desconsiderados.

Contudo, o confronto das formulações dos intelectuais e artistas sobre o modo como deveria ser representado o "nacional-popular" na cultura brasileira aponta para um cenário rico em contradições, diferente do caráter mo- 
nolítico e homogêneo atribuído ao CPC, via de regra associado integralmente às teses de Carlos Estevam Martins.

Ocorre que, na virada dos anos 50 para os 60, configurou-se no Brasil um debate intenso em torno da ideologia do nacionalismo, debate esse que influenciou inúmeras instituições, partidos políticos e movimentos sociais. Para o PCB, um dos mais expressivos partidos políticos de esquerda de então, a construção dessa ideologia nacionalista se traduziu, em linhas gerais, na articulação de uma "frente única", isto é, na organização de uma unidade política a partir de segmentos sociais distintos com o intuito de realizar no país uma revolução baseada nos princípios do antifeudalismo e do antiimperialismo, com ênfase no caráter nacional e democrático. ${ }^{4}$

Essa articulação se concretizou, na área da produção artístico-cultural, na constituição de uma pedagogia estética voltada, sobretudo, para a classe média intelectualizada e na adaptação do "nacional-popular". Segundo Ferreira Gullar, então integrante do CPC, não se tinha "essas teorias complicadas do nacional-popular, ninguém pensava isso. Agora, nós achávamos que devíamos valorizar a cultura brasileira, que devíamos fazer um teatro que tivesse raízes na cultura brasileira, no povo, na criatividade brasileira". ${ }^{5}$ No mesmo sentido afirma Celso Frederico:

não se falava, ainda, no nacional-popular de Gramsci, autor praticamente desconhecido entre nós. Trilhando um caminho paralelo, os comunistas acenavam para uma conceituação próxima à gramsciana. É difícil precisar a origem dessa formulação. ${ }^{6}$

Nesse contexto de interpretação do "nacional-popular" e consolidação da ideologia nacionalista, atores, dramaturgos, diretores, produtores e companhias teatrais com vínculos ideológicos com o "movimento nacionalista brasileiro" procuraram, diferentemente, politizar e popularizar o teatro brasileiro.

E o que caracterizou o teatro brasileiro das décadas de 1950 e 1960 - isto é, o aperfeiçoamento técnico, a formação de platéia e a especialização de atores, cenógrafos, figurinistas e diretores - não compensava a ausência de uma dramaturgia e repertório nacionais. Foi assim que começaram a surgir inúmeras críticas ao repertório e ao público tradicionais das companhias teatrais da época. Do ponto de vista da qualidade estética dos espetáculos e dos lucros de bilheteria, o Teatro Brasileiro de Comédia - TBC, que era um dos mais bem-sucedidos teatros do período, foi também o mais visado e critica- 
do por essa vertente engajada do teatro brasileiro. Na dianteira dessa oposição estava o Teatro de Arena de São Paulo que, em 1956, após se unir ao Teatro Paulista do Estudante - TPE e contratar Augusto Boal, procurava, além de resistir às pressões econômico-financeiras e à concorrência das grandes empresas teatrais, criar uma identidade própria para o primeiro teatro em formato de arena da América do Sul, ou seja, uma identidade fundada na dramaturgia e na arte cênica brasileiras. ${ }^{7}$

Essa mudança temática e estética do teatro brasileiro, influenciada, sobretudo, pelo quadro aqui traçado, já estava sendo aguardada pelos seus contemporâneos. O crítico Haroldo Santiago, por exemplo, considerou que a

afluência de diretores europeus se por um lado impulsionou-nos esteticamente, e não podemos negá-lo, por outro lado impediu, ou melhor, adiou por algum tempo a construção de um teatro realmente brasileiro, já que estes encenadores trouxeram da Europa toda uma concepção de teatro que nos era socialmente estranha e que necessitaria de algum tempo para ser digerida e transformada em organismo vivo. ${ }^{8}$

A partir daí, Oduvaldo Vianna Filho, ex-integrante do TPE, que nesse meio-tempo estava trabalhando no Rio de Janeiro, voltou para o Teatro de Arena em São Paulo. Dois fatores contribuíram consideravelmente para esse retorno: 1) o sucesso (de público e bilheteria) da peça Eles não usam blacktie, de Gianfrancesco Guarnieri; e 2) a organização do Seminário de Dramaturgia, por Augusto Boal. No que diz respeito a Guanieri, com a intenção de fundamentar as preocupações estéticas e ideológicas implícitas na peça Eles não usam black-tie, publicou, em 1959, o artigo "O teatro como expressão da realidade nacional”, delimitando os pressupostos teóricos da arte e do teatro "nacional-popular". Segundo ele,

a obra dos novos autores brasileiros demonstra claramente a necessidade geral de tratar de temas sociais, problemas de nosso povo em nosso tempo, o que nos dá a medida de quanto nossa juventude se aflige com os problemas atuais e quanto os artistas jovens procuram participar dessas lutas. ${ }^{9}$

Quanto à programação do Seminário de Dramaturgia organizado por Boal, atendia à seguinte divisão: 1) Parte prática: a) Técnica de dramaturgia; e b) Análise e debate de peças; 2) Parte teórica: a) Problemas estéticos do teatro; b) Características e tendências do teatro moderno brasileiro; c) Estudo 
da realidade artística e social brasileira; d) Entrevistas, debates e conferências com personalidades do teatro brasileiro. ${ }^{10}$ Apesar de toda afinidade política expressa em suas iniciativas junto ao Arena, as divergências não tardaram a aparecer. Insatisfeito com o público que acreditava pautar-se pelo sucesso de bilheteria e não pela qualidade artística do espetáculo, ${ }^{11}$ Vianninha resolveu viajar, em 1959, acompanhando a turnê do Teatro de Arena para o Rio de Janeiro, onde apresentaram Eles não usam black-tie, de Gianfrancesco Guarnieri, Chapetuba Futebol Clube, de Oduvaldo Vianna Filho, e Revolução na América do Sul, de Augusto Boal. No Rio de Janeiro, além da apresentação das peças teatrais, o grupo organizou também, sob a direção de Oduvaldo Vianna Filho, seminários de dramaturgia e ciclos de estudos teatrais sobre as obras de Bertolt Brecht e Erwin Piscator.

Nesses anos, as divergências entre Oduvaldo Vianna Filho e José Renato acerca do modelo administrativo adotado pelo então diretor do Teatro de Arena se acentuavam cada vez mais. Com a intenção de resolver essas diferenças e não optar pelo desligamento do Teatro de Arena, Oduvaldo sugeriu, em 1960, que a companhia teatral deveria ligar-se a entidades estudantis, partidos políticos, instituições científicas e sindicatos. ${ }^{12}$

A partir dessa perspectiva de aproximação com outras linguagens e ambientes, Oduvaldo Vianna Filho iniciou a redação de uma peça que aproximava o teatro brasileiro do vocabulário marxista. $\mathrm{O}$ aparato teórico sobre o problema da "mais-valia" na sociedade capitalista foi proporcionado por uma das principais instituições da época: o ISEB. Por intermédio de Francisco de Assis, que já freqüentava a instituição, Oduvaldo Vianna Filho conheceu Carlos Estevam Martins, então assistente de Álvaro Vieira Pinto, que contribuiu para a elaboração de roteiros, cartazes e slides que visavam apresentar didaticamente a lógica da "mais-valia" para os atores, diretores e dramaturgos que se instalaram na Faculdade Nacional de Arquitetura do Rio de Janeiro.

$\mathrm{O}$ afastamento de Oduvaldo Vianna Filho do Teatro de Arena então se concretizou. O público do Teatro de Arena não condizia com as expectativas de Vianninha acerca da politização e nacionalização do teatro brasileiro. Assim, endossar o modelo empresarial adotado por José Renato - para um autor que "defendeu posições e se engajou em torno de palavras de ordem e de estratégias de luta" ${ }^{13}$ — era o mesmo que trair sua própria consciência, forjada no âmbito da aliança de classes.

Compreendida a partir do contexto histórico da época, a peça A maisvalia vai acabar, Seu Edgar transformou-se em peça-modelo ou peça-síntese das novas propostas teatrais do Teatro de Arena e posteriormente do CPC. A 
utilização de linguagem direta, cartazes, slides e números musicais ${ }^{14}$ facilitava a absorção dos conceitos marxistas pelo público, isto é, a compreensão de como esses conceitos interferiam na vida cotidiana das pessoas.

Antes que terminassem a temporada da peça e o grupo se dispersasse, Oduvaldo Vianna Filho, Carlos Estevam Martins e Leon Hirszman propuseram à recém-eleita direção da União Nacional dos Estudantes - UNE a realização de um curso de filosofia ministrado pelo professor José Américo Mota Pessanha. Assim, A mais-valia vai acabar, Seu Edgar, dirigida por Francisco de Assis e apresentada no Teatro da Faculdade Nacional de Arquitetura do Rio de Janeiro, contribuiu para a organização de artistas, estudantes e intelectuais e conseqüentemente para a criação do CPC.

No artigo "Do Arena ao CPC", ${ }^{15}$ Oduvaldo Vianna Filho expôs os principais motivos que o influenciaram a sair do Teatro de Arena e fundar o CPC. Novamente, a preocupação com o público do teatro se apresentou com intensidade. $\mathrm{O}$ acordo de união entre o Teatro de Arena e o TPE estabelecia

um amplo movimento teatral de apoio e incentivo ao autor e obras nacionais, visando à formação de um numeroso elenco que permitia a montagem simultânea de duas ou mais peças, levando o teatro a fábricas, escolas, faculdades, clubes da capital e do interior do estado, sem prejuízo do funcionamento normal do teatro, contribuindo assim para a difusão da arte cênica em meio às mais diversas camadas do nosso povo. ${ }^{16}$

Assim, o modelo empresarial adotado por José Renato, além de romper com esse acordo, não correspondia às inquietações iniciais dos jovens dramaturgos, isto é, um teatro mais democrático que atingisse também as massas. ${ }^{17}$ Essa contradição expressou-se nas palavras de Oduvaldo Vianna Filho: "o Arena era porta-voz das massas populares num teatro de cento e cinqüenta lugares”."18

$\mathrm{O}$ argumento empregado pelo dramaturgo acerca da incompatibilidade entre atividade teatral e atividade empresarial já havia sido utilizado anteriormente por outros autores. A opção pelo público "burguês" não é entendida como uma opção da direção do Teatro de Arena, mas como uma limitação estrutural. Pouco antes, Haroldo Santiago já dizia que a principal diferença entre o Teatro de Arena e as demais companhias teatrais situava-se no campo das intenções ideológicas: “o T. A. visa comunicar-se com um público mais popular enquanto que os outros grupos querem continuar no mesmo padrão de clientela, isto é, os espectadores que se sujeitam a uma etiqueta mais ou menos rígida e podem pagar uma exorbitância pelo ingresso". ${ }^{19}$ E nas linhas 
seguintes considerava que foi no preço dos ingressos que o Teatro de Arena falhou. ${ }^{20}$

A conscientização dos quadros e classes populares através da linguagem teatral era um dos objetivos buscados por dramaturgos como Oduvaldo Vianna Filho e Gianfrancesco Guarnieri desde os tempos do TPE. Mas quem poderia garantir que esse era o objetivo do Teatro de Arena enquanto empresa do ramo teatral? Se o fosse, as pretensões de atuação como cooperativa não seriam abandonadas em função do caráter empresarial adotado posteriormente; afinal, dificilmente a realização de um teatro popular sem subsídios governamentais ou empresariais sobreviveria no cenário brasileiro somente com a apresentação em fábricas, sindicatos, universidades ou centros comunitários. Assim,

a opção do Arena era fatal e a atitude de seus membros ilustrou a escolha a que foram forçados. Os que mantiveram o nome do grupo basicamente se restringiram a platéias da alta classe-média, que podem pagar ingressos. Serve de exemplo a última temporada no Rio, com a Mandrágora de Maquiavel, cujos preços e propósitos muito se afastavam dos sonhos iniciais de ver Eles não usam black-tie no Sindicato dos Metalúrgicos. Outros componentes do Arena se fixaram no Rio e partiram para uma experiência diferente. Desistindo do profissionalismo em bases comerciais, lançaram no Teatro da Faculdade de Arquitetura o movimento que viria a dar origem ao Teatro Jovem e aos Centros Populares de Cultura da UNE. ${ }^{21}$

Para Oduvaldo Vianna Filho, "o Arena contentou-se com a produção de cultura popular, não colocou diante de si a responsabilidade de divulgação e massificação", ${ }^{22}$ ponto nevrálgico da atuação do CPC, entendido pelo teatrólogo como uma tentativa de suprir as principais deficiências e limitações do "inconformado" Teatro de Arena (já assimiladas as categorias de artista "conformado", "inconformado" e "revolucionário"). ${ }^{23}$

Estratégia semelhante foi apresentada no artigo "Cultura popular: conceito e articulação", publicado na revista Movimento, dois números antes do artigo "Do Arena ao CPC". Ou seja, duas fases distintas estão presentes no momento de organização dos CPCs: "quem leva cultura, quem recebe cultura”. ${ }^{24}$ Esse tipo de ação cultural foi apresentado também no Relatório do Centro Popular de Cultura, cujo movimento de cultura popular se daria através da atuação de dois grupos inicialmente distintos: a atuação para os grupos sociais e a atuação com os grupos sociais. ${ }^{25}$ 
O arranjo de sistemas teóricos e políticos de pensadores e estadistas (Hegel, Husserl, Mannheim, Marx, Engels, Lênin, Stálin, Mao Tse Tung, Che Guevara, Lukács ou Sartre) na produção teórico-prática do CPC foi realizada, em grande parte, não sobre a leitura direta da obra de cada um dos referidos autores, mas sobre uma interpretação favorecida pelos intelectuais do ISEB. ${ }^{26}$ Posteriormente, com o contato direto de estudantes e artistas com tais obras, esse quadro foi sendo alterado. Depois disso é que os conceitos elaborados por autores como Lukács, Gramsci, Sánchez Vázquez e Benjamin foram absorvidos e adaptados diretamente pelos ativistas do CPC.

Sob essa perspectiva pode-se analisar o conceito de alienação associado à ideologia do nacionalismo como sustentáculo para as múltiplas reflexões acerca da "cultura popular" nos anos 60 . Ao definirem como sinônimos popular e nacional, ${ }^{27}$ os intelectuais e artistas do CPC incorporaram a versão de Roland Corbisier, membro do ISEB, sobre a relação alienação-colonialismo/dependência/subdesenvolvimento versus desalienação-metrópole/independência/desenvolvimento.

Nesse sentido, o livro Formação e problema da cultura brasileira ${ }^{28}$ teve suas principais teses reproduzidas e assimiladas por Carlos Estevam Martins, Nelson Lins de Barros e Ferreira Gullar, entre outros. Francisco de Assis chegou a dizer: "por isso eu ficava lá no ISEB horas a fio, ouvindo aquelas fitas. Uma coisa que me impressionou muito, na época, foi uma tese do Roland Corbisier sobre cultura e desenvolvimento. Ele colocava, de maneira bastante clara, um negócio que eu, depois, desenvolvi bastante". ${ }^{29}$

Inspirado no artigo "Le colonialisme est un système", de Jean-Paul Sartre, tudo seria subdesenvolvido no subdesenvolvimento para Roland Corbisier. Aceitando a priori a correspondência direta entre o plano econômico (infraestrutura) e o plano cultural (superestrutura), Roland Corbisier considerava necessária a elaboração prévia de um projeto nacional, capaz de superar e romper com as estruturas coloniais amparadas, sobretudo, na atividade agrícola, e promover a emancipação econômica e cultural através da industrialização brasileira. Isso o levou a argumentar que "no plano econômico, a colônia exporta matéria-prima e importa produto acabado, assim também, no plano cultural, a colônia é material etnográfico que vive da importação do produto cultural fabricado no exterior". ${ }^{30}$ E no parágrafo seguinte conclui: "exportamos o não ser e importamos o ser. Somos o invólucro vazio de um conteúdo que não é nosso porque é alheio. Enquanto colônia não temos forma própria porque não temos destino". ${ }^{31} \mathrm{O}$ consumo do "ser" do "outro", portanto, representava a própria alienação da sociedade brasileira, pois 
importar o produto acabado é importar o ser, a forma, que encarna e reflete a cosmovisão daqueles que a produziram. Ao importar, por exemplo, o cadillac, o chiclete, a coca-cola não importamos apenas objetos ou mercadorias, mas também todo um complexo de valores e de condutas que se acham implicados nesses produtos. ${ }^{32}$

Assim, somente a formulação (prévia) de um projeto voltado para o desenvolvimento econômico e cultural brasileiro seria capaz de criar mecanismos e instrumentos para a transformação de uma cultura "inautêntica" fruto da dominação econômica e ideológica da metrópole - para uma cultura "autêntica" - cuja autonomia permite pensar a própria realidade do país. No plano econômico, a industrialização se transformou no principal caminho para conquistar essa autonomia. No plano cultural, era preciso encontrar mecanismos equivalentes à industrialização para promover o desenvolvimento, ${ }^{33}$ já que

a transformação das estruturas de base, que implica a substituição das importações, a criação da indústria nacional e do mercado interno ... se realiza ... por meio de comportamentos livres, racionalmente planejados e executados. Essa transformação das estruturas de base ... acarreta e provoca, por sua vez, transformações paralelas e simétricas no plano da educação e da cultura. ${ }^{34}$

A reinterpretação das principais teses dos isebianos, entre as quais as de Roland Corbisier, foi amplamente assimilada por estudantes, artistas e intelectuais do CPC. O que se pode dizer, portanto, é que o CPC, sob o apoio da UNE, inspirou-se esteticamente no Teatro de Arena e ideologicamente no PCB e no ISEB.

Sobre os vínculos da UNE com o CPC, pode-se classificar este como uma organização administrativa e financeiramente autônoma, característica acentuada pelo regimento interno do CPC, aprovado em Assembléia Geral em 8 de março de 1962. No início, essa independência não se caracterizava como problema ou empecilho para a UNE. Mas nos anos que antecederam ao golpe militar, a disputa pela hegemonia do movimento estudantil favoreceu o surgimento de organizações político-partidárias divergentes que contribuíram para o aparecimento de dissidências na UNE. Esse quadro afetou o CPC quando a direção da UNE quis submetê-lo às suas decisões políticas. Na segunda UNE-Volante o conflito tornou-se explícito: o CPC se recusou a for- 
necer seus quadros para o evento e a UNE teve de contratar artistas que não pertenciam àquela entidade, ao menos formalmente. ${ }^{35}$

Entre a fundação em $1961^{36}$ e a extinção em março de 1964, três nomes integraram a direção do CPC. O primeiro, Carlos Estevam Martins; o segundo, Carlos Diegues, e o terceiro e último, Ferreira Gullar. O CPC que pretendia inicialmente manter e fortalecer o grupo formado com as apresentações da peça A mais-valia vai acabar, Seu Edgar já apresentava, como o movimento estudantil, suas dissidências. Nos dois últimos anos, havia pelo menos duas correntes distintas no interior do CPC: uma corrente liderada por Oduvaldo Vianna Filho e outra por Carlos Estevam Martins, esta ainda vinculada às idéias e teses do "manifesto do CPC". A experiência do CPC gerou, anos depois, uma literatura revisionista. Porém, no que se refere aos principais objetivos do "manifesto do CPC", Carlos Estevam Martins não mudou integralmente de opinião. No depoimento concedido a Jalusa Barcellos, comentou:

lembro-me de uma festa no Largo do Machado. Do outro lado da praça, tinha um pessoal com um berimbau que conseguiu muito mais público que a gente. $\mathrm{E}$ olha que nós estávamos lá com aquela carreta cheia de luz, som, o diabo... Quando voltamos de lá, tivemos uma sessão de autocrítica que foi pesada. Eu acabei com a vida dos caras. Falei: "Não é possível uma coisa dessa, fazer um troço popular que está numa linguagem que não atrai o povo. Tem algum troço errado aqui”. Estava sofisticado demais, tinham que baixar o nível de sofisticação. Essa foi a grande luta que eu sempre travei lá. Porque eu, como não era artista, via aquilo por outro ângulo. $O$ pessoal de vocação artística queria fazer coisas de valor estético... ${ }^{37}$

Após breve interinidade de Carlos Diegues (permaneceu apenas três meses como presidente do CPC), a ascensão de Ferreira Gullar para a presidência significou um acordo político para amenizar os impasses entre Oduvaldo Vianna Filho e Carlos Estevam Martins. Nessa fase, ao defender espetáculos elaborados artisticamente e voltados para um público diversificado, Oduvaldo estava mais próximo da dissidência do Cinema Novo do que dos ideais de "arte popular revolucionária" de Estevam. ${ }^{38}$ Por exemplo, no artigo "O teatro popular não desce ao povo, sobe ao povo", Oduvaldo posicionou-se contra o "manifesto do CPC" ao declarar que "não há que, em nome da participação, baixar o nível artístico das obras de arte, diminuir sua capacidade de apreensão sensível do real, estreitar a riqueza de emoções e significações que ela po- 
de nos emprestar", ${ }^{39}$ pois "acreditamos que seremos mais eficazes quanto mais artisticamente comunicarmos a realidade". ${ }^{40}$

Além dessas divergências, nesse contexto ficou também conhecido o embate estético-ideológico travado entre Oduvaldo Vianna Filho e Leandro Konder sobre a função social da arte e o modo como conduzir as políticas culturais ${ }^{41}$ do CPC. Konder defendia os princípios estéticos de Lukács (contrários ao caráter panfletário considerado ineficiente tanto no plano político como no plano estético). Já Oduvaldo, preocupado também com os resultados práticos da ação cultural, desconsiderava o caráter estritamente teórico e, segundo ele, pouco eficaz quando destinado à transformação efetiva da sociedade brasileira. Considerava as idéias de Leandro Konder em descompasso com as políticas culturais executadas pelos ativistas do CPC e não se cansava de repetir: "Pô, lá vem você com Lukács. Você é um chato!". 42

A divergência entre Oduvaldo Vianna Filho e Leandro Konder, tendo como pivô Lukács, pode ser considerada uma exceção entre os debates da época, pois o acesso às obras de autores como Benjamin, Gramsci e Lukács foi inexpressivo nos anos que precederam ao golpe militar. Assim, a divergência levada a público serviu para inaugurar um debate múltiplo acerca da arte engajada. Mas, de qualquer forma, somente nos anos que se seguiram ao golpe de 1964 é que tais autores foram lidos com mais atenção e intensidade e, nesse contexto, é representativo o trabalho e a iniciativa de editoras, revistas e intelectuais que contribuíram para que essas idéias chegassem a um número cada vez maior de pessoas.

Como se pode perceber, a trajetória de Oduvaldo Vianna Filho caracteriza-se pela revisão constante dos próprios escritos e também dos escritos de outros teóricos. Isso pode explicar parcialmente por que na década de 1960 surgiram inúmeras concepções de cultura popular. Num determinado momento, Oduvaldo reproduziu os esquemas sintéticos sobre a função social da arte (representada pelas categorias "arte popular", "arte do povo" e "arte popular revolucionária" ou pela polaridade "arte pura" versus "arte participante”) e, em outra ocasião, abandonou-os em função da impossibilidade de aceitar o dilema que lhe era colocado: "para que haja mensagem, não é possível fazer arte". ${ }^{43}$ No decorrer dos anos, percebe-se que o teatrólogo revisou suas idéias sobre a cultura popular e sobre as condições de difusão da produção artística. 


\section{MANIFESTO DO CPC: UMA CARTA DE INTENÇÕES}

Ao elaborar uma concepção rígida e excludente sobre a "arte popular revolucionária" e um modelo limitado e proibitivo para a produção artísticocultural, Estevam fez emergir (e esse talvez tenha sido o principal mérito do "manifesto do CPC") uma série de controvérsias e dissidências. Segundo Leandro Konder,

o CPC nasceu muito sectário. O documento programático, de autoria do Carlos Estevam Martins, era um negócio meio aterrador, aquela divisão de arte popular, arte para o povo, arte popular revolucionária, sendo que só a arte popular revolucionária era boa, as outras duas eram alienadas. Eu achei aquilo um horror. Posteriormente, o CPC na prática foi retificando a linha, mas eu fiquei sempre preso àquela primeira imagem. Então, eu discutia com o Vianinha e ele me dizia: "Você está com essa mania de Lukács".44

Apesar da intenção de formular uma concepção de "arte popular revolucionária" com base no "nacional-popular", é possível perceber no "manifesto do CPC” claros vestígios de uma política cultural próxima ao realismo socialista, na medida em que Carlos Estevam Martins considerou que a distinção que separava

os artistas e intelectuais do CPC dos demais grupos e movimentos existentes no país é a clara compreensão de que toda e qualquer manifestação cultural só pode ser adequadamente compreendida quando colocada sob a luz de suas relações com a base material sobre a qual se erigem os processos culturais de superestrutura. ${ }^{45}$

Assim, três alternativas se impunham aos artistas e intelectuais: o "conformismo", o "inconformismo" e a "atitude revolucionária". ${ }^{46}$ Para Estevam, a simples negação da ideologia opressora caracterizada pelo inconformismo não era suficiente para a atitude revolucionária. Como observou Oduvaldo Vianna Filho, "o Arena, sem contato com as camadas revolucionárias de nossa sociedade, não chegou a armar um teatro de ação, armou um teatro inconformado". ${ }^{47}$ E para o "manifesto do CPC", "os membros do CPC optaram por ser povo, por ser parte integrante do povo, destacamentos de seu exército no front cultural". ${ }^{48}$ Assim, "ou ficamos com o que caminha para a destruição, ou ficamos com o que surge, com o "novo", 49 e o novo, segundo esse ponto de vista, é o povo. ${ }^{50}$ 
Carlos Estevam Martins, então, definiu “arte do povo" "arte popular" e "arte popular revolucionária":

a arte do povo é predominantemente um produto das comunidades economicamente atrasadas e floresce de preferência no meio rural ou em áreas urbanas que ainda não atingiram as formas de vida que acompanham a industrialização. $\mathrm{O}$ traço que melhor a define é que nela o artista não se distingue da massa consumidora. Artista e público vivem integrados no mesmo anonimato e o nível de elaboração artística é tão primário que o ato de criar não vai além de um simples ordenar os dados mais patentes da consciência popular atrasada. A arte popular, por sua vez, se distingue desta não só pelo seu público que é constituído pela população dos centros urbanos desenvolvidos, como também devido ao aparecimento de uma divisão de trabalho que faz da massa a receptora improdutiva de obras que foram criadas por um grupo profissionalizado de especialistas. Os artistas se constituem assim num estrato social diferenciado de seu público, o qual se apresenta no mercado como mero consumidor de bens cuja elaboração e divulgação escapam ao seu controle..$^{51}$

Para Estevam, "a arte do povo e a arte popular quando consideradas de um ponto de vista cultural rigoroso dificilmente poderiam merecer a denominação de arte; por outro lado, quando consideradas do ponto de vista do CPC de modo algum podem merecer a denominação de popular ou do povo", ${ }^{52}$ assim "só se pode falar de uma arte do povo e de uma arte popular porque se tem em vista uma outra arte ao lado delas, ou seja, a arte destinada aos círculos culturais não populares". ${ }^{33}$

Diferentemente do espaço destinado à definição de "arte do povo" e "arte popular", à "arte popular revolucionária” foram destinados inúmeros parágrafos ao longo do "manifesto do CPC". Em linhas gerais, a "arte popular revolucionária" e

a declaração dos princípios artísticos do CPC poderia[m] ser resumida[s] na enunciação de um único princípio: a qualidade essencial do artista brasileiro, em nosso tempo, é a de tomar consciência da necessidade e da urgência da revolução brasileira, e tanto da necessidade quanto da urgência. ${ }^{54}$

Então, para conscientizar o "povo” brasileiro, as preocupações estéticas e formalistas deveriam ser subjugadas a fórmulas de fácil compreensão.

Para Marilena Chauí, a "cultura de massa" foi reduzida pelo "manifesto 
do CPC” à distração e ao escapismo, com brevíssima alusão às demandas e determinações de mercado. ${ }^{55}$ Sob outro prisma, Renato Ortiz avaliou que a ausência de discussões sobre a cultura de massa nesse período pode demonstrar o caráter incipiente da indústria cultural nas décadas de 1940, 50 e início de 60. Para o autor, "há um relativo silêncio sobre a existência de uma 'cultura de massa', assim como sobre o relacionamento entre produção cultural e mercado ... É somente em 1966 que vamos encontrar um primeiro artigo de Ferreira Gullar sobre a estética na sociedade de massa". ${ }^{56}$

No entanto, preocupado com o processo de produção da obra de arte, José Guilherme Merquior, em artigo publicado no início de 1963, tentou preencher as lacunas deixadas pelo "manifesto do CPC" no que diz respeito à criação, divulgação e recepção do produto artístico ${ }^{57}$ Foi através do artigo "Notas para uma teoria da arte empenhada" que o autor manifestou antes de 1966 a preocupação com o processo de produção da obra de arte na sociedade de massa (preocupação esta que será apresentada mais adiante).

As coordenadas do "manifesto do CPC" sobre a arte de modo geral ("do povo", "popular" e "popular revolucionária”), constituíram uma forma de negação explícita da interpretação promovida anteriormente pelos folcloristas. Ainda que algumas perspectivas desses pesquisadores fossem recuperadas posteriormente, é possível perceber em autores como Carlos Estevam Martins, Ferreira Gullar e Nelson Lins de Barros uma espécie de negação absoluta da concepção de folclore e cultura popular romanticamente idealizada pelos folcloristas, em que o significado do termo popular está diretamente associado às manifestações culturais das classes populares que preservariam uma cultura antropológica, conservada em museus e necessária para alimentar o saber nostálgico dos intelectuais tradicionais. ${ }^{58}$ Assim, Estevam foi enfático ao dizer, em nome dos artistas e intelectuais do CPC, que

repudiamos a concepção romântica própria a tantos grupos de artistas brasileiros que se dedicam com singela abnegação a aproximar o povo da arte e para os quais a arte popular deve ser entendida como formalização das manifestações espontâneas do povo. Para tais grupos o povo se assemelha a algo assim como um pássaro ou uma flor, se reduz a um objeto estético cujo potencial de beleza, de força primitiva e de virtudes bíblicas ainda não foi devidamente explorado pela arte erudita. ${ }^{59}$

A contradição entre forma e conteúdo, qualidade e popularidade ou comunicação e expressão - justificada pela (não) liberdade de criação do ar- 
tista e pela (in)capacidade de assimilação do público — vê-se simplificada quando abordada a relação entre o artista, a obra e o público. Não é à toa que uma das principais polêmicas suscitadas pelo "manifesto do CPC" diz respeito à liberdade de expressão do artista no processo de criação da obra. Segundo Estevam, os membros do CPC optaram por ser povo, por ser parte integrante do povo. ${ }^{60}$ A partir dessa opção obrigatória, cabe ao "artista revolucionário" privar-se conscientemente de alguns recursos técnicos e formais próprios a sua classe de origem, com a finalidade de ser entendido pelo público que escolheu defender. Público este que, segundo Estevam, privado das condições materiais, não teve acesso às formas mais requintadas de criação artística.

Por isso, as críticas são remetidas ao teor dos trabalhos realizados pelos integrantes do CPC, já que a orientação era priorizar o conteúdo em detrimento da forma. Para Carlos Estevam Martins, do ponto de vista formal, os artistas do CPC seriam capazes de reconhecer o valor da denominada "arte ilustrada”. Entretanto, o mesmo não ocorria em relação ao conteúdo, pois segundo o autor

a chave que elucida todos os problemas relativos às possibilidades formais da arte ilustrada e da arte revolucionária é descoberta quando se compreende que o ato de criar está determinado em sua raiz pela opção original a que nenhum artista pode se esquivar e que consiste no grande dilema entre a expressão e a comunicação. ${ }^{61}$

Ao investigar o engajamento da literatura e da prosa especificamente, Jean-Paul Sartre considerou que o escritor, ao escolher o seu leitor, escolhe também um aspecto do mundo que deseja desvendar. ${ }^{62}$ Só assim é que o artista revolucionário rompe com a idéia de inferioridade estética em função do estabelecimento da comunicação com a classe "oprimida" da qual escolhe fazer parte, por natureza ou, ao menos, pelo espírito.

No Brasil, nos anos 60, Sartre constituiu-se em referência obrigatória, ${ }^{63}$ principalmente no que se refere ao posicionamento tomado pelo filósofo entre 1945 e 1968. Nesse período, Sartre — o "filósofo da liberdade, da consciência e do humanismo" (como ficou conhecido) - constatou que tanto o "moralismo" quanto o "realismo" estavam presos às malhas do mundo social objetivo. A despeito de sua relação conturbada com o Partido Comunista Francês - PCF, o que descobriu nesses anos foi a necessidade de assimilar o vocabulário marxista, afinal era preciso incorporar uma forma de pensamen- 
to que não estivesse sintonizada com os escritores anteriores, obviamente sem renunciar à autonomia de pensamento.

Assim, o problema colocado de acordo com a forma e o conteúdo na obra de arte se resolveria, para Estevam, no momento em que o artista decidisse priorizar a comunicação em detrimento da expressão com um fim único e exclusivo: comunicar-se com as massas. A partir disso, o único desafio a ser enfrentado pelos artistas do CPC relacionava-se com a contradição entre qualidade e popularidade:

surge para o artista revolucionário na razão direta do seu pertencimento a um estrato cultural distinto e superior ao do seu público. ${ }^{64}$

desejando acima de tudo que sua arte seja eficaz, o artista popular não pode jamais ir além do limite que lhe é imposto pela capacidade que tenha o espectador para traduzir, em termos de sua própria experiência, aquilo que lhe pretenda transmitir o falar simbólico do artista. ${ }^{65}$

cabe-lhe ainda realizar o laborioso esforço de adestrar seus poderes formais a ponto de exprimir correntemente na sintaxe das massas os conteúdos originais de sua intuição, sem que percam todo o seu sentido ao serem convencionalizados e transplantados para o mundo das relações inter-humanas em que a massa vive sua existência cotidiana. ${ }^{6}$

A partir desses pressupostos do "manifesto do CPC", o que definiu a superioridade da "arte popular revolucionária" em relação a outras formas de manifestações artístico-culturais foi a possibilidade de criação a partir da realidade social existente. Ou melhor, "só a arte revolucionária, que não teme o real porque tudo que dele vem caminha em seu benefício, está em condições de tomar fenômenos e essências sem mistificar o seu verdadeiro significado, sem isolá-los abstrata e mecanicamente". ${ }^{67}$

No espaço das políticas culturais promovidas sob a sigla do CPC, essas idéias de Estevam foram reproduzidas, assimiladas e, sobretudo, contestadas por inúmeros artistas. Oduvaldo Vianna, por exemplo, questionou a suposta superioridade da "arte popular revolucionária" quando considerou que

não é possível reunir as grandes obras ou fazer uma identidade única que as separa das obras populares, das obras efêmeras. As grandes obras, as realizações artísticas mais acabadas e densas se dividem quanto à sua perspectiva do problema do homem — são reacionárias ou progressistas. O mesmo acontece com 
as obras correntes, com o abastecimento cultural constante e cotidiano das grandes massas. ${ }^{68}$

Apesar da pertinência das críticas endereçadas ao "manifesto do CPC", é problemático concordar com a visão de superfície das análises que tomaram o documento como síntese da produção artística engajada de uma geração, de um artista ou mesmo de uma obra específica. A afirmação de Marcos Napolitano, nesse sentido, é importante na medida em que apresenta o "manifesto do CPC" como "carta de intenções" ideológicas, e não propriamente como um documento de regras técnico-estéticas para a produção artística da canção engajada. ${ }^{69}$

Portanto, vários são os problemas que emergem das abordagens que tomaram o "manifesto do CPC" como um fim em si mesmo, isto é, que não procuraram analisar a correspondência entre um suposto projeto estético e político elaborado por Carlos Estevam Martins e a produção artística veiculada pelo CPC. Um exemplo representativo dessa perspectiva de análise é a coleção O nacional e o popular na cultura brasileira, cujo primeiro volume, Seminários, escrito por Marilena Chauí, é o mais significativo entre os seis exemplares publicados sob a coordenação do Núcleo de Estudos e Pesquisas da Fundação Nacional das Artes - Funarte. Marilena Chauí é perspicaz ao identificar nos estudantes, artistas e intelectuais o público alvo do CPC. Entretanto, uma educação política e estética voltada principalmente para a formação da própria intelectualidade não é entendida como um dos principais objetivos do CPC, mas como um "desvio" dos objetivos promulgados pela entidade. Segundo a autora, “visto que ‘ser povo’ é uma 'opção', o 'Manifesto', deixando de lado o 'povo', entabula um diálogo inter pares com outros intelectuais e artistas".70

O debate destacado até aqui procura situar a demarcação dos limites do “manifesto", já que as diferentes linguagens artísticas envolvidas nesse processo não podem ser resumidas a uma forma única de representação. Por isso, a especificidade formal do teatro, do cinema e da música é extremamente significativa e singular, a ponto de se ver reduzida à concepção linear do "manifesto do CPC".

Uma das formas possíveis para analisar a integração entre os artistas, os intelectuais e as massas, nos anos 60, seria compreender a produção artísticocultural financiada ou vinculada ao CPC como uma espécie de educação política e estética voltada primeiramente para a constituição de uma intelectualidade engajada, capaz de "iluminar ou sensibilizar e, possivelmente, conscientizar 
setores das classes médias sobre a pobreza e a miséria reinante no Brasil". ${ }^{71}$ Assim, o artigo "Cultura popular: conceito e articulação" — "quem leva cultura, quem recebe cultura", ${ }^{72}$ o Relatório do Centro Popular de Cultura - atuação para e com grupos sociais, ${ }^{73}$ e o livro Cultura posta em questão, de Ferreira Gullar - para e com as massas, ${ }^{74}$ apresentaram diversas etapas de organização e atuação do CPC.

Embora o artigo "Cultura popular: conceito e articulação" reproduza as principais coordenadas do "manifesto do CPC", a ação de cultura popular proposta pelo documento considerava necessário ter uma opção definitiva (e inédita para a época) diante do povo: "o povo sendo um mero consumidor de cultura criada pelas minorias e pelas elites; ou o povo sendo o criador das condições materiais que permitem a elaboração da cultura não podendo o povo ser dela alienado". ${ }^{75}$

No artigo, a politização do "povo brasileiro" deveria passar pelas seguintes fases: 1) criação de um movimento de cultura popular e mobilização da intelectualidade da Guanabara; e 2) ampliação do conhecimento da realidade brasileira e aprofundamento da comunicação com o povo. Para concretizar os principais objetivos do CPC, a primeira etapa, situada na atuação para grupos sociais, estava voltada para a organização e formação de uma intelectualidade comprometida com a realidade brasileira. ${ }^{76} \mathrm{~A}$ segunda etapa, baseada na atuação com os grupos sociais, estava voltada para a união e formação do povo não somente como recebedor, mas também como criador de cultura. ${ }^{77}$

Na maioria das formulações sobre "cultura popular" promovidas pelos integrantes do CPC através, sobretudo, da revista Movimento, da UNE, e do jornal O Metropolitano, da União Metropolitana de Estudantes - UME, é possível identificar nas idéias de conscientização do "povo" o objetivo central das propostas cepecistas. Mas também é preciso considerar as fases de mobilização dos quadros (atuação para e com os grupos sociais).

Os documentos de época mostram também que a criação do CPC não se deu através de um projeto prévio e definido, além, é claro, da vontade desordenada de promover a cultura popular, a partir da qual a intelectualidade conduziria a sua produção teórico-prática. Mas uma estrutura em constante transformação na medida em que novas propostas e objetivos eram formulados e incorporados segundo as necessidades dos próprios quadros. Sendo assim, no final de 1963 foi criado um Grupo de Trabalho - GT de reestruturação do $\mathrm{CPC}$ - “a atual organização do CPC tem caráter transitório, como se depreende do GT de Reestruturação" 78 — com a tarefa "de propor uma no- 
va estrutura orgânica para a entidade, capaz de atender à necessidade de crescimento do CPC". ${ }^{79}$

O poeta e engenheiro Marcos Konder Reis, por exemplo, orientado pelas informações fornecidas por Carlos Estevam Martins (então diretor geral do CPC) afirmou que a entidade era dividida em: Assembléia Geral; Conselho Consultivo; Diretor Geral, encarregado de coordenar a Direção de Administração e Produção, a Direção Cultural e Editorial, a Direção Artística, a Direção de Indústria e Arte Cinematográfica, a Direção de Realização, a Direção de Vendas e Publicidade e a Direção de Coordenação do Movimento de Conscientização das Massas; Departamento Financeiro; FILMEX e PRODAC. ${ }^{80}$

Outro documento, redigido provavelmente pela equipe de redação do CPC por volta de setembro de 1963, informa a organização interna do CPC, estruturada em seis grupos de trabalho (GT de Repertório, GT de Construção do Teatro; GT de Cinema; GT de Espetáculos Populares; GT da Produtora de Arte e Cultura e GT de Reestruturação), um conselho diretor composto de dois representantes de cada GT e um coordenador. ${ }^{81}$

Manoel Tosta Berlinck, um dos primeiros pesquisadores (senão o primeiro) a adotar o CPC como objeto de pesquisa, constatou que a organização da instituição estruturava-se em Assembléia Geral; Conselho Diretor (Diretor Executivo e Coordenadores dos Departamentos); departamentos artísticos e administrativos. Primeiramente foram criados os departamentos de Teatro (subdividido em Teatro Convencional e Teatro de Rua) e Cinema, em seguida foram criados os departamentos de Música, Arquitetura, Artes Plásticas e Administração e, por último, foram criados os departamentos de Alfabetização para Adultos e Literatura. Também criou-se o departamento de Relações durante a I UNE-Volante e a editora PRODAC, encarregada de distribuir livros e discos produzidos pelo CPC..$^{82}$

A constante revisão das atividades junto à intelectualidade e às classes populares conduziu os integrantes na procura de caminhos capazes de resolver as inúmeras contradições pelas quais passava o CPC frente à crítica de então, cujo teor poderia ser sintetizado no fato de que se falava constantemente do povo e não para o povo. Aliás, a formação do CPC pretendia atuar inicialmente a partir da prática e não da teoria, pois acreditava-se que

a fase inicial é a da mobilização dos levadores de cultura. Para isso é preciso ir à prática sem exigir muito da qualidade dos resultados, é preciso trazer o problema da cultura popular à consciência social. Atuar, mesmo sem uma programa- 
ção definida, aproveitar todas as possibilidades de representar, de escrever, de fazer cartazes, de fazer música. ${ }^{83}$

A atuação, portanto, não era pautada por um projeto pré-concebido. Logo, não se pode analisar o "manifesto do CPC" como uma política ou projeto cultural previamente elaborado, já que a prática das ações político-culturais os levaria à constituição de uma teoria e não o inverso.

Comparado ao movimento do Cinema Novo, que surge a partir de um projeto ${ }^{84}$ os estudantes, artistas e intelectuais cepecistas não falavam em estabelecer projetos culturais ou artísticos. O fato explica, em parte, o embate de Oduvaldo Vianna Filho com Leandro Konder citado anteriormente. Revisando anos depois as suas divergências estético-ideológicas, Konder - questionado por Oduvaldo Vianna Filho quanto à (in)eficiência das teorias de Lukács aplicadas à ação cultural dos ativistas do CPC - considerou que no geral Oduvaldo tinha razão. ${ }^{85}$

Com ou sem razão, no que diz respeito ao alcance da produção cepecista, a intelectualidade era consciente da atuação limitada da entidade, voltada para e com os universitários. Assim, uma redefinição da sua participação fazia-se necessária. Afinal, como chegar às massas atuando tão-somente para e com estudantes, artistas e intelectuais? O relatório do CPC registrou a preocupação com a reduzida atuação entre universitários e buscou aprofundar e estender a atuação entre outros grupos sociais, sobretudo, entre as classes populares rural e urbana: "acreditamos que a maioria dos ativistas da cultura popular, inicialmente, devem estar entre os universitários — talvez seja universitário o primeiro grupo social a ser atingido. Mas jamais deve haver grupos permanentemente voltados com exclusividade para os universitários", 86 criando então uma "verdadeira liga estudantil operário-camponesa". ${ }^{87}$

Assim, acredita-se que a atuação do CPC voltou-se para a educação estética e política dos próprios quadros, já que a integração e a conscientização das classes populares concretizou-se timidamente quando comparada à mobilização e formação de intelectuais e artistas de classe média. Em decorrência do golpe militar, a extinção dos CPCs e o incêndio da sede da UNE contribuíram para inibir qualquer tentativa de contato com as classes populares, sobretudo no que se refere às entidades de representação (sindicatos, associações, fábricas etc.).

Nesse mesmo relatório é possível situar a entidade no que concerne à educação estética e política da própria classe média, representada na figura 
dos universitários: "universitários foram mobilizados e escreveram, representaram, debateram, fizeram exposições, formaram-se e formaram, conheceram as limitações objetivas para os movimentos de culturalização, adaptaram seus meios aos seus fins".88

Ainda que timidamente exercida pelo departamento de teatro e cinema, a relação híbrida entre intelectualidade e classes populares se consolidou de forma peculiar através da atuação do departamento de música do CPC. Sob esse prisma, a I Noite de Música Popular, realizada em 16 de dezembro de 1962 no Teatro Municipal, e os três Festivais de Cultura Popular promovidos respectivamente em 17 de setembro de 1962, fevereiro e 9 de setembro de 1963, destacaram-se entre as atividades exercidas pelo CPC.

Considerando, então, a produção artístico-cultural do CPC sob a perspectiva de educação estética e política da classe média, procurou-se revisar a literatura que, nos anos de 1970 e, sobretudo, 1980, criou um viés interpretativo comum a muitas análises que, de modo geral, partiram do princípio de que o CPC não atingiu seu principal objetivo, isto é, chegar às massas.

Renato Ortiz, ainda que tenha analisado as atividades da entidade através do conceito de "hegemonia" de Antonio Gramsci, ou seja, distanciandose em teoria e método de outros autores, não rompeu com a interpretação corrente. ${ }^{89}$ Para o autor, a definição gramsciana de "ideologia" (isto é, cultura popular e nacionalismo não são apresentados sob a égide do conceito de "alienação"), anulou a discussão sobre a "autenticidade" e "inautenticidade" das concepções de mundo, colocando-as em termos de relações de força. Apresentou a "alienação" popular ou nacional sob o conceito da hegemonia, seja de uma classe sobre outra, seja de uma nação sobre outra.

Sem se diferenciar das análises sobre o CPC realizadas nas décadas de 1950, 60, 70 e, sobretudo, 80, ${ }^{90}$ Renato Ortiz afirmou que "pode-se considerar aqui a mesma crítica que Gramsci estabelece com relação às obras de Manzoni; o povo é o personagem principal da trama artística, mas na realidade se encontra ausente". ${ }^{11}$ De modo geral, assumiu a interpretação até então proposta, isto é, reforçar a contradição entre as idéias e as ações dos intelectuais e artistas do CPC.

Com a preocupação de não reproduzir os mesmos argumentos, procurou-se investigar as obras e os agentes sociais vinculados, direta ou indiretamente, ao CPC do ponto de vista da formação de uma nova classe média no âmbito da sociedade brasileira.

Não se descarta, no entanto, que o distanciamento entre público-autor, 
acentuado por Ortiz, transformou-se num aspecto importantíssimo a ser observado na produção artístico-cultural da época. Mas essa mesma produção deve ser observada dentro dessas etapas de atuação dos ativistas. Em apenas dois anos de existência, consolidou-se a primeira etapa (atuação para os grupos sociais). E, embora iniciada, a segunda etapa (atuação com os grupos sociais), foi interrompida com o incêndio da sede da UNE em $1^{\circ}$ de abril de 1964. Mas ainda assim é possível perceber a integração — entre artistas do CPC e artistas populares ou entre artistas e "público alvo" - em eventos como a I Noite de Música Popular, por exemplo. Do golpe militar em diante, a integração entre os artistas do CPC e os artistas populares foi representada no show "Opinião", enquanto a utopia do artista engajado de chegar às massas passava a ser comercializada pelos meios de comunicação de massa, em especial a televisão.

As análises de pesquisadores citados anteriormente — Luiz Antônio Afonso Giani, Enor Paiano, Arnaldo Daraya Contier, Marcos Napolitano e Marcelo Ridenti - sobre o caráter heterogêneo e desagregador do "manifesto do CPC” e sobre a participação e contribuição da produção cepecista, são fundamentais para problematizar essa questão. Enor Paiano, por exemplo, considera de extrema importância "pensar de que maneira conceitos colocados em jogo a partir da atividade do CPC moldaram posturas, debates, criações, iniciativas e desequilibraram o jogo de forças no campo intelectual". ${ }^{22}$

Como já se evidenciou neste artigo, as lacunas e principalmente as limitações teóricas em torno da concepção de "cultura de massa" presente, ou melhor, ausente no "manifesto do CPC", foram questionadas e complementadas por José Guilherme Merquior em artigo intitulado "Notas para uma teoria da arte empenhada", uma das primeiras tentativas de fundamentar uma teoria da arte empenhada partindo da situação concreta do processo artístico moderno, considerando a edição, a distribuição e a recepção da obra de arte. Afinal, "a criação de novos hábitos estéticos por meio de novas técnicas, a constituição de novas relações entre obra e público, afetam o desenvolvimento, e decidem a sobrevivência, de toda a arte geral dos tempos". ${ }^{93}$

A introdução da problemática no Brasil foi possibilitada pela introdução de autores da Escola de Frankfurt nas reflexões acerca da "cultura de massa", sendo o ensaísta Walter Benjamin ${ }^{94}$ uma referência permanente, quer para José Guilherme Merquior, quer para Ferreira Gullar. Mas isso, como já foi dito, foram manifestações isoladas, uma vez que tais referências tornaram-se constantes apenas no período posterior ao golpe de 1964. 
Considerada como distração e escapismo por Marilena Chaui ${ }^{95}$ ou como resultado do caráter ainda incipiente da indústria cultural no país por Renato Ortiz, ${ }^{96}$ a ausência ou limitação de uma concepção de cultura de massa no "manifesto do CPC" foi ampliada e questionada segundo o conceito de "arte empenhada” por José Guilherme Merquior. Em contraposição à "arte de vanguarda", considerada decadente, a "arte empenhada" denominada "nova arte popular" deveria estar fundamentada na teoria do realismo. Para Merquior,

da atitude e do vigor de enfrentar criticamente o mundo, e, para transformá-lo, descobrir na realidade a esfera do possível objetivo, da possibilidade concreta, no sentido em que todo grande realismo tem sido sempre uma compreensão e um apego ao que existe, em nome de uma perspectiva transformadora. ${ }^{97}$

No sentido de estimular "o empenho de uma arte voluntária e conscientemente didática, devotada à formação de um novo homem brasileiro", 98 era preciso questionar e contestar, segundo Merquior, uma possível conceituação baseada em fatores reducionistas e excludentes. Numa espécie de resposta ou repulsa ao "manifesto do CPC", o autor enumerou os possíveis enganos e ilusões provocados pela desordenada conceituação de "cultura" e "arte popular":

há o perigo de se atribuir à divulgação popular um valor exclusivo, o perigo de se impor unicamente uma arte plebéia, mudando "popular" em "populista"; o perigo de instituir, como conceito de arte empenhada, um desprezo geral pela nossa comum cultura burguesa, erro dos mais fáceis, dos mais sedutores para a ignorância e para o improviso, e que repousa na cândida idéia de que o mundo começa com o socialismo; o perigo sectário, que pode substituir ao alargamento político e estreitamento partidário; o perigo de estabelecer um "dirigismo" cultural às custas da livre crítica e da criação desempedida $[s i c] .{ }^{99}$

Essa acusação de dirigismo estético-ideológico foi uma das principais causas do desentendimento entre os cineastas do CPC e Carlos Estevam Martins, levando aqueles à aproximação com o movimento então conhecido como Cinema Novo.

As principais atividades do CPC sempre estiveram vinculadas à produção de "cultura popular". Entretanto, distinta da interpretação adotada pelos intelectuais folcloristas, um novo significado é atribuído ao termo como explicou Carlos Estevam Martins a Marcos Konder Reis: 
a cultura que o CPC propõe-se a levar ao povo é aquela que seus membros chamam de cultura para a libertação. Trata-se da utilização da vanguarda cultural para a conscientização do povo, o que lhe facultará, posteriormente, a tomada do poder. A cultura para a libertação é, portanto, como podemos inferir, uma cultura essencialmente política. ${ }^{100}$

Porque "fora da arte política não há arte popular". ${ }^{101}$ Assim, determinar a diferença entre os termos "cultura popular" e "folclore", apresentados como sinônimos pela geração anterior, se transformou num dos principais objetivos de teóricos como Carlos Estevam Martins e Ferreira Gullar. Não é à toa que logo na primeira linha, do primeiro parágrafo, da primeira página do livro Cultura posta em questão, Ferreira Gullar, para evitar qualquer analogia, tomou a precaução de grafar o termo cultura popular entre aspas, definindoo como um fenômeno novo no contexto histórico brasileiro. ${ }^{102}$ Elias Chaves Neto, redator da Revista Brasiliense, ao evidenciar a receptividade da primeira apresentação da peça Eles não usam black-tie, montada pelo CPC em São Paulo no dia 18 de junho de 1962, já atentava para a peculiaridade desse fenômeno. Igualmente para o redator,

tudo isto é novo. Tudo isto faz pressentir o aparecimento de um novo tipo de cultura, cultura popular, cultura viva, ligada à solução dos problemas do nosso País e aos ideais de paz e felicidade pelos quais aspira toda a humanidade ... O Centro Popular de Cultura está sendo no momento o porta-estandarte deste novo tipo de cultura que está se formando em nosso País. ${ }^{103}$

Compreender a agitação em torno da "cultura popular" implica, portanto, considerar tanto o sentimento de esperança, quanto a profunda convicção na singularidade do processo histórico brasileiro em voga. ${ }^{104}$

A “cultura popular", entendida como uma das possibilidades de transformação da realidade brasileira, através da arregimentação da intelectualidade e da conscientização das classes populares, foi fundamentada, sobretudo, na idéia de "frente única”. Ou seja, esses artistas e intelectuais de esquerda acreditavam que a "cultura popular" - apoiada em organizações estudantis, operárias e camponesas - seria capaz de promover profundas transformações na estrutura sócio-econômica e nas relações de poder no Brasil. ${ }^{105}$ Logo, entendida como revolucionária (e não como reformista) pelos próprios protagonistas. 
Daí, a importância da UNE e dos CPCs como promotores da "cultura popular” através, sobretudo, das UNEs-Volantes, da organização de seminários e da participação em campanhas públicas em prol do movimento nacionalista brasileiro. Nesse sentido, a "cultura popular" promovida pela intelectualidade vinculada ideologicamente ao CPC foi sinônimo de "consciência revolucionária”. ${ }^{106}$ Por isso, segundo Ferreira Gullar, "o que é importante é que se recupera a visão correta da cultura e se parte da constatação para a ação". ${ }^{107}$

A configuração da "cultura popular" a partir da reinterpretação do termo convoca a participação dos intelectuais como agentes ativos do processo revolucionário em curso no país. A primeira grande batalha da intelectualidade pela "cultura popular" (de cárater nacional e nacionalista) foi travada contra o imperialismo, o que não significa ignorar ou extirpar as influências externas já enraizadas no processo de formação cultural, social, política e econômica da sociedade brasileira. Com relação às influências externas era necessário, segundo Ferreira Gullar, assimilar criticamente os valores e os princípios exteriores, não implicando anulação ou entrave da consciência do intelectual acerca da própria realidade nacional. ${ }^{108}$ Assim, levando-se em conta o fato de que

tal influência é sempre positiva quando se exerce sobre culturas com a consistência necessária para absorver dela o que é útil, fecundo, e rejeitar o resto. Mas, nos países em formação, as influências externas tendem, muitas vezes, a agir como fator de perturbação do processo formativo, introduzindo desvios e discrepâncias que só se dão devido à fragilidade do movimento cultural implantado. ${ }^{109}$

Ferreira Gullar, ao comentar o caráter "maléfico" da influência externa como instrumento de dominação imperialista, transportou para a intelectualidade a função de conscientização das classes populares, pois só assim passariam de meros consumidores (quando consumidores) para produtores de "cultura popular". Portanto, concretizadas as etapas de arregimentação da intelectualidade e conscientização do "povo brasileiro",

é necessário desenvolver uma ação mais próxima da massa, não apenas produzindo obras "para" ela como procurando trabalhar "com" ela, visando tanto desenvolver, nela, os meios de comunicação e produção cultural, como obter, nesse trabalho, um conhecimento mais objetivo de determinada comunidade que permite maior eficácia na elaboração da obra que seja dirigida à massa. ${ }^{110}$ 
A publicação do livro Cultura posta em questão foi tão acidentada como qualquer outra forma de expressão ou veículo de comunicação reprimido nos anos 60, em decorrência do golpe militar e da promulgação gradativa dos atos institucionais. Redigido em janeiro de 1963, o livro foi editado em 1964 pela editora Civilização Brasileira. Entretanto, foi tirado de circulação pela polícia política, encarregada de censurar e reprimir manifestações artísticas e intelectuais consideradas "subversivas" e, para evitar maiores problemas com o aparelho repressor, o livro foi reeditado como primeira edição em 1965, ${ }^{111}$ quando essa já era a segunda edição.

A "cultura popular" definida superficialmente por Carlos Estevam Martins e aprofundada por Ferreira Gullar nessa obra em particular, foi questionada e rebatida por pesquisadores e críticos que se dedicaram a analisar a produção artístico-cultural dos anos 60, sobretudo pelo fato de serem acusados de utilizar a arte como instrumento de ação política. Ferreira Gullar tampouco ficou isento de indagações e contestações, principalmente ao adotar a polaridade entre "arte pura" e "arte comprometida" como justificativa para a atuação do CPC. Por isso foi acusado de transportar, para o âmbito dos debates estético-ideológicos, traços das políticas culturais ortodoxas, principalmente ao empregar as designações "descomprometidos" e "comprometidos". ${ }^{112}$

Tendo em vista o caráter desnorteado e desordenado do debate em torno da "cultura popular" promovida pelos ativistas do CPC, Gullar considerou válido, assim como Estevam, a manipulação de recursos formais em função do alcance do público. Não obstante, não analisa essa "manipulação" como redução estética, mas como visões-de-mundo e princípios estético-ideológicos diferentes. A incompreensão do ponto de vista adotado pela intelectualidade do CPC levou pesquisadores e críticos a acusar, segundo Ferreira Gullar, de esteticamente inferiores as obras de arte produzidas sob o rótulo genérico de "participante". ${ }^{113}$ Essa perspectiva parece ter sido incorporada pela literatura de modo geral.

Levando em conta todos os possíveis equívocos da definição de "cultura popular”, não se questiona a importância da produção artística e intelectual da época, sobretudo como documento histórico. Mas, é preciso considerar que o "produto" artístico gerado nos anos 60 - entendido como resultado da interação entre produção (artista, tema e tecnologia), divulgação (mecanismos mercadológicos) e recepção (público) — não pode ser analisado tãosomente como reflexo das formulações teóricas acerca das definições de "cultura" e "arte popular" empreendidas pelos artistas e intelectuais do CPC. 
A conceituação de cultura popular empreendida por Ferreira Gullar como "um fenômeno novo na vida brasileira, cuja importância está na razão direta dos complexos fatores sociais que o determinam" "114 não foi entendida pelo crítico Clarival Valladares, o que desencadeou um debate entre este e o poeta sobre o livro Cultura posta em questão, através da resenha "Uma questão de cultura", de Valladares, ${ }^{115}$ e da resposta "Sim, uma questão de cultura", de Gullar. ${ }^{116}$

A crítica presente na resenha "Uma questão de cultura" relacionou-se à confusão conceitual que faz Ferreira Gullar ao definir indistintamente os termos “civilização", "cultura" e "povo". Segundo o crítico, Ferreira Gullar "não tem o direito de inverter o sentido dos termos, de perverter os conceitos e os fundamentos do conhecimento humanístico". ${ }^{117}$ Ora, ao tomar conhecimento das teses de Roland Corbisier sobre a cultura brasileira, percebe-se quais foram as bases teóricas, entre outras, de Ferreira Gullar para conceituar a "cultura popular". Por isso, o livro Formação e problema da cultura brasileira constitui-se num dos principais referenciais teóricos (mas não o único) para os artistas e intelectuais da época. Conforme Roland Corbisier,

ao empregar a expressão "cultura brasileira", de cuja formação vamos nos ocupar, não nos queremos referir apenas aos aspectos intelectual e artístico, religioso, literário ou científico de nossa cultura, mas à totalidade das manifestações vitais, que, em seu conjunto, caracterizam e definem o povo brasileiro. A palavra é empregada no mesmo sentido em que os franceses costumam usar a palavra civilização, com o qual designam o objeto próprio da história, seja a de toda a humanidade, seja a de cada povo em particular. Poderíamos, assim, desde que nos entendêssemos previamente sobre o sentido dos termos, dar a uma história de nosso País o título de História da Civilização ou da Cultura Brasileira. ${ }^{118}$

Então, o não entendimento da "cultura popular" como um fenômeno específico, segundo Gullar, distinto das manifestações culturais do povo, levou Clarival Valladares à incompreensão da problemática do livro: "a necessidade de compreender-se a cultura como uma questão social concretamente determinada e que, numa sociedade de classes, não pode isentar das contradições peculiares a essa mesma sociedade". ${ }^{119}$ Quando Gullar afirmou que "cultura popular é, portanto, antes de mais nada, consciência revolucionária”, ${ }^{120}$ estava atribuindo responsabilidade social aos intelectuais, já que "uma das maneiras, que tem o intelectual de ajudar nessa transformação, é desmistificar o conceito de 
cultura que a apresenta como um universo fechado em si mesmo, acima das questões sociais e infenso a elas". ${ }^{121}$ É evidente a intenção de diferenciar "cultura popular" de "folclore", pois quando analisadas como sinônimos, a definição de cultura popular recupera a noção de tradição, cuja ênfase no caráter tradicional implica a perpetuação e a conservação da ordem estabelecida. Enquanto para a intelectualidade do CPC "cultura popular" significava justamente o contrário: transformação da ordem estabelecida, mesmo que hoje essa transformação seja entendida como reformista e não revolucionária.

Portanto, as ações reformistas ou radicais não pressupõem, como sugere Octávio Ianni, ${ }^{122}$ insubordinação à ordem estabelecida. Para Antonio Candido o trabalho de investigação das idéias radicais na história do Brasil proporciona os "instrumentos que permitem a consciência clara do rumo que as transformações podem e devem tomar”. ${ }^{123}$ Apesar dos fatores negativos - como os elementos de atenuação, e mesmo de oportunismo inconsciente, que podem desviar o curso das transformaçõe ${ }^{124}$ - o autor considera fundamental a presença das propostas radicais (ou reformistas, como denominaram Weffort e Ianni) nos países subdesenvolvidos, em que o "nível de consciência política do povo não corresponde à sua potencialidade revolucionária”. ${ }^{125}$ Ao valorizar o papel transformador dos "radicalismos" como agente do "possível" mais avançado para as transformações "viáveis" da sociedade brasileira ou como "condição de êxito do pensamento revolucionário, inclusive o que se inspira no marxismo", ${ }^{126} \mathrm{o}$ autor apresentou uma nova perspectiva analítica para a abordagem do problema. Assim, "um dos critérios para avaliar a radicalidade de um político ou intelectual brasileiro é averiguar o que ele considera povo, num país de tão grande variedade cultural e racial". ${ }^{127}$

O caráter desordenado da "cultura popular" definida pelos artistas e intelectuais do CPC proporcionou uma espécie de fio condutor para averiguar os principais impasses e contradições da intelectualidade brasileira preocupada com a politização das artes no Brasil. O "manifesto do CPC", comumente analisado como síntese da produção artístico-cultural da época, é entendido como uma espécie de ponto de referência e não como projeto cultural e que foi reproduzido, assimilado e, sobretudo, contestado pelos principais artistas e intelectuais que se dispuseram a pensar, pressupondo sua prática, políticas culturais para o CPC.

Assim, a apresentação das principais discussões e debates acerca da função social da arte, da cultura popular e do engajamento artístico demonstram que a politização (traduzida pelas políticas culturais de nacionalização e po- 
pularização da obra de arte) não seguiu uma fórmula pronta ou projeto mestre, mas foi caracterizada por uma série de idéias e planos que, apesar de partirem do "manifesto do CPC", jamais reproduziram automaticamente suas principais teses.

O que evidencia então a inquietação desses artistas e intelectuais é a heterogeneidade dessas produções artístico-culturais que se vincularam direta ou indiretamente ao CPC. A pluralidade dos debates em torno do engajamento da arte e do próprio artista realizado nos anos que antecederam ao golpe militar é tão intensa e marcante que dificulta determinar unilateralmente qualquer característica, rótulo, projeto ou política cultural, tanto para os seus protagonistas, quanto para as suas produções artístico-culturais.

\section{NOTAS}

${ }^{1} \mathrm{O}$ artigo que ora se apresenta é parte de uma pesquisa de mestrado realizada no Programa de Pós-Graduação em História da Universidade Federal do Paraná (UFPR), orientada pelo Prof. Dr. Marcos Napolitano e financiada pela Coordenadoria de Aperfeiçoamento de Pessoal de Nível Superior (CAPES). In: SOUZA, M. G. de. Do Arena ao CPC: o debate em torno da arte engajada no Brasil (1959-1964). Curitiba, 2002. Dissertação (Mestrado em História) — Setor de Ciências Humanas, Letras e Artes, Universidade Federal do Paraná.

${ }^{2}$ Sobretudo GIANI, L. A. A. A Música de Protesto: do subdesenvolvimento à canção do bicho e proezas de satanás... (1962-1966). Campinas, 1986. Dissertação (Mestrado em Sociologia) - IFCH, Universidade Estadual de Campinas; PAIANO, E. O berimbau e o som universal: lutas culturais e indústria fonográfica nos anos de 1960. São Paulo, 1994. Dissertação (Mestrado em Comunicações) — Escola de Comunicação e Artes, Universidade de São Paulo; CONTIER, A. D. Edu Lobo e Carlos Lyra: o nacional e o popular na canção de protesto (os anos de 1960). Revista Brasileira de História, São Paulo, v.18, n.35, p.13-52, 1998; NAPOLITANO, M. Seguindo a canção: engajamento político e indústria cultural na trajetória da MPB (1959/1969). São Paulo, 1999. Tese (Doutorado em História) — FFLCH, Universidade de São Paulo; RIDENTI, M. Em busca do povo brasileiro: artistas da revolução, do CPC à era da TV. Rio de Janeiro: Record, 2000.

${ }^{3}$ Sobre a relação entre populismo e nacionalismo consultar: WEFFORT, F. C. O populismo na política brasileira. Rio de Janeiro: Paz e Terra, 1978, 181p., e IANNI, O. O colapso do populismo no Brasil. 4.ed. Rio de Janeiro: Civilização Brasileira, 1978, 223p. Ver também: GOMES, A. de C. O populismo e as ciências sociais: notas sobre a trajetória de um conceito. In: FERREIRA, J. (Org.) O populismo e sua história: debate e crítica. Rio de Janeiro: Civilização Brasileira, 2001, 380p., p.17-57. 
${ }^{4}$ As principais características da "frente única" estão mais bem detalhadas na Declaração sobre a política do Partido Comunista Brasileiro, de março de 1958. In: PCB: vinte anos de política, 1958-1979: documentos. São Paulo: LECH, 1980, 353p. (A Questão Social no Brasil, 7), p.3-27.

${ }^{5}$ Apud RIDENTI, op. cit., p.128.

${ }^{6}$ FREDERICO, C. A política cultural dos comunistas. In: MORAES, J. Q. de. (Org.) História do Marxismo no Brasil — v.III: teorias. interpretações. Campinas: Ed. Unicamp, 1998, 382p. (Coleção Repertórios), p.277.

${ }^{7}$ Cabe ressaltar que essa preocupação foi se estruturando aos poucos, já que, no período de 1953 a 1955, o Teatro de Arena era, segundo Sábato Magaldi, "uma espécie de TBC pobre, ou econômico", cujo repertório se concentrava nos clássicos europeus, sobretudo. In: MAGALDI, S. Um palco brasileiro: o Arena de São Paulo. São Paulo: Brasiliense, 1984, 100p. (Coleção Tudo é História, 85), p.7.

${ }^{8}$ SANTIAGO, H. Teatro nacional popular. Brasiliense, São Paulo, n.26, p.198-201, nov./dez. 1959, p.199. Aqui, e nas demais citações, a grafia está sendo atualizada.

${ }^{9}$ GUARNIERI, G. O teatro como expressão da realidade nacional. Brasiliense, São Paulo, n.25, p.121-6, set./out. 1959, p.122.

${ }^{10}$ In: MAGALDI, op. cit., p.33.

${ }^{11}$ Apud MORAES, D. de. Vianinha: cúmplice da paixão. Rio de Janeiro: Record, 2000, 418p., p.90.

${ }^{12}$ VIANNA FILHO, O. O artista diante da realidade [1960]. In: PEIXOTO, F. (Org.) Vianinha: teatro, televisão e política. São Paulo: Brasiliense, 1983.223p. (Antologias e biografias), p.65.

${ }^{13}$ PATRIOTA, R. Vianinha: um dramaturgo no coração de seu tempo. São Paulo: Hucitec, 1999, 229p. (Teatro, 39), p.106.

${ }^{14}$ Incorporação dos procedimentos técnicos adotados por Bertolt Brecht sobretudo em $O$ coro dos contrários.

${ }^{15}$ Inicialmente publicado na revista Movimento em 1962, o artigo foi transcrito na coletânea de textos de Oduvaldo Vianna Filho organizada por Fernando Peixoto. VIANNA FILHO, O. Do Arena ao CPC [1962]. In: PEIXOTO, op. cit., p.90-5.

${ }^{16}$ Apud MORAES, op. cit., p.58-9.

${ }^{17}$ A mesma indisposição que caracterizou a relação conturbada de José Renato e Oduvaldo Vianna Filho transferiu-se, anos depois, para o embate entre Carlos Estavam Martins e Oduvaldo Vianna Filho sobre a administração do CPC, embate este analisado nas próximas páginas. 
${ }^{18}$ VIANNA FILHO, Do Arena ao CPC, p.93.

${ }^{19}$ SANTIAGO, op. cit., p.201.

${ }^{20}$ Ibidem.

${ }^{21}$ ROCHA FILHO. In: ROCHA FILHO et al. Teatro Popular. Cadernos Brasileiros, v.6, n.3, p.40-55, maio/jun. 1964, Mesa Redonda, p.43.

${ }^{22}$ VIANNA FILHO, Do Arena ao CPC, p.93.

${ }^{23}$ MARTINS, C. E. Anteprojeto do Manifesto do Centro Popular de Cultura redigido em março de 1962. In: HOLLANDA, H. B. de. Impressões de viagem: CPC, vanguarda e desbunde: 1960/1970. São Paulo: Brasiliense, 1980, p.121-44.

${ }^{24}$ Cultura popular: conceito e articulação. Movimento, Rio de Janeiro, n.4, p.11-2, jul. 1962, p.12, grifos nossos.

${ }^{25}$ RELATÓRIO do Centro Popular de Cultura [1962]. In: BARCELLOS, J. CPC da UNE: uma história de paixão e consciência. Rio de Janeiro: Nova Fronteira, 1994. 472p. p.44156, p.444, grifos nossos.

${ }^{26}$ Sobretudo, Roland Corbisier, Hélio Jaguaribe, Nelson Werneck Sodré, Roberto de Oliveira Campos, Álvaro Vieira Pinto, Cândido Mendes e Alberto Guerreiro Ramos, que desde 1956 constituíam seminários do ISEB promovidos em conjunto com o Ministério da Educação e Cultura - MEC.

${ }^{27}$ Nelson Werneck Sodré afirmou que "em política, como em cultura, só é nacional o que é popular". In: SODRÉ, N. W. Quem é o povo no Brasil? Rio de Janeiro: Civilização Brasileira, 1962. 61p. (Coleção Cadernos do Povo Brasileiro), p.17; e Ferreira Gullar considerou que a "cultura popular tem caráter eminentemente nacional e mesmo nacionalista". In: GULLAR, F. Cultura posta em questão. Rio de Janeiro: Civilização Brasileira, 1965, 126p., p.9.

${ }^{28}$ CORBISIER, R. Formação e problema da cultura brasileira. Rio de Janeiro: ISEB, 1958, 88p. (Textos Brasileiros de Filosofia, 3).

${ }^{29}$ In: BARCELLOS, op. cit., p.144.

${ }^{30}$ CORBISIER, op. cit., p.69.

${ }^{31}$ Ibidem, p.70.

${ }^{32}$ Ibidem, p.69.

${ }^{33}$ Ibidem, p.69-70.

${ }^{34}$ Ibidem, p.85.

${ }^{35}$ BERLINCK, M. T. O Centro Popular de Cultura da UNE. Campinas: Papirus, 1984. 120p. (Coleção Krisis), p.23-4.

${ }^{36}$ Para o relatório do CPC, a entidade havia sido fundada em março de 1961. In: RELA- 
TÓRIO..., p.441; e, para Manoel Tosta Berlinck, o CPC foi criado em dezembro de 1961. In: BERLINCK, op. cit., p.9.

${ }^{37}$ In: BARCELLOS, op. cit., p.89-90, grifos nossos.

${ }^{38}$ Consultar o debate promovido pela revista Senhor sobre "cultura popular" e o artigo "Cinema Novo: a cultura popular revisitada”. In: SOUZA, M. G. de. Cinema Novo: a cultura popular revisitada. História: questões e debates, Curitiba, v.20, n.38, p.133-59, jan./jun. 2003. ${ }^{39}$ VIANNA FILHO, O. O teatro não desce ao povo, sobe ao povo. [19-] In: MICHALSKI, Y. (Org.) Teatro de Oduvaldo Vianna Filho - v.1. Rio de Janeiro: Ilha, 1981, 378p., p.210, p.13.

${ }^{40}$ Ibidem, p.14.

${ }^{41}$ Sobre o conceito de políticas culturais ver: BRUNNER, J. J. La mano visible y la mano invisible. In: América Latina: cultura y modernidade. México: Grijalbo, 1992.

${ }^{42}$ Apud MORAES, op. cit., p.132.

${ }^{43}$ VIANNA FILHO, “O teatro não desce...”, p.13.

${ }^{44}$ Apud RIDENTI, op. cit., p.76.

${ }^{45}$ MARTINS, op. cit., p.123.

${ }^{46}$ Ibidem, p.126.

${ }^{47}$ VIANNA FILHO, “Do Arena ao CPC”, p.93.

${ }^{48}$ MARTINS, op. cit., p.127.

${ }^{49}$ GUARNIERI, G. O teatro como expressão da realidade nacional. Brasiliense, São Paulo, n.25, p.121-6, set./out. 1959, p.124.

${ }^{50}$ MARTINS, op. cit., p.127.

${ }^{51}$ Ibidem, p.129-30, grifos nossos.

${ }^{52}$ Ibidem, p. 130 .

${ }^{53}$ Ibidem.

${ }^{54}$ Ibidem, p. 143.

${ }^{55}$ CHAUÍ, M. Seminários. São Paulo: Brasiliense, 1983, 106p. (O Nacional e o Popular na Cultura Brasileira), p.91.

${ }^{56}$ ORTIZ, R. A moderna tradição brasileira: cultura brasileira e indústria cultural. São Paulo: Brasiliense, 1988, 223p., p.14-5.

${ }^{57}$ MERQUIOR, J. G. Notas para uma teoria da arte empenhada. Movimento, Rio de Janeiro, n.9, p.13-7, mar. 1963.

${ }^{58}$ ORTIZ, Moderna tradição..., p.160-2. 
${ }^{59}$ ESTEVAM, op. cit., p.132.

${ }^{60}$ Ibidem, p.127.

${ }^{61}$ Ibidem, p. 135 .

${ }^{62}$ SARTRE, J.-P. Que é a literatura? Trad. Carlos Felipe Moisés. São Paulo: Ática, 1989, 231p. (Original: Qu'est-ce que la litterature?, p.58.).

${ }^{63}$ De passagem pelo Brasil em 1960, Sartre apresentou uma conferência sobre a noção do belo e da beleza na Universidade Mackenzie de São Paulo. In: SARTRE, J.-P. Conferência de Jean-Paul Sartre — Universidade Mackenzie - 1960. Trad. Maria Porto, p.7-32.

${ }^{64}$ MARTINS, op. cit., p. 138.

${ }^{65}$ Ibidem.

${ }^{66}$ Ibidem, p.139.

${ }^{67}$ Ibidem, p.141.

${ }^{68}$ VIANNA FILHO, Do Arena ao CPC, p. 94.

${ }^{69}$ NAPOLITANO, Seguindo a canção..., p.56.

${ }^{70}$ In CHAUÍ, op. cit., p.86.

${ }^{71}$ CONTIER, op. cit., p.31.

${ }^{72}$ Cultura popular: conceito..., p.12.

${ }^{73}$ RELATÓRIO..., p.444.

${ }^{74}$ GULLAR, Cultura posta..., p.6.

${ }^{75}$ Cultura popular: conceito..., p.11.

${ }^{76}$ RELATÓRIO..., p.444.

${ }^{77}$ Ibidem.

${ }^{78}$ Ibidem, p.442.

${ }^{79}$ Ibidem.

${ }^{80}$ REIS, M. K. Centro Popular de Cultura. Cadernos Brasileiros, v.5, n.1, p.78-82, jan./fev. 1963, p.79.

${ }^{81}$ RELATÓRIO..., p.442.

${ }^{82}$ BERLINCK, op. cit., p.27.

${ }^{83}$ Cultura popular: conceito..., p. 12 .

${ }^{84}$ Segundo Glauber Rocha, "em 1959 [sic, na verdade trata-se de 1957, data que pode ser precisada pela realização de Rio, Zona Norte] passo em Belo Horizonte onde proponho àqueles intelectuais [da Revista de Cinema] o lançamento do Cinema Novo mas sou con- 
siderado visionário e expulso de Belo Horizonte vou ao Rio e levo o projeto a Nelson Pereira dos Santos que estava filmando Rio, Zona Norte". Apud RAMOS, F. Os novos rumos do cinema brasileiro (1955-1970). In: RAMOS, F. (Org.) História do cinema brasileiro. São Paulo: Art Editora, 1987, 555p., p.309.

${ }^{85}$ Apud MORAES, op. cit., p.132.

${ }^{86}$ RELATÓRIO..., p.445.

${ }^{87}$ LYRA, C. In: BARCELLOS, op. cit., p.96.

${ }^{88}$ RELATÓRIO..., p.446-7, grifo nosso.

${ }^{89}$ De acordo com Renato Ortiz, "apesar das intenções, o distanciamento público-autor é uma constante; um exemplo patético disto são as produções artísticas realizadas pelo CPC". In: ORTIZ, R. Cultura brasileira e identidade nacional. 2.ed. São Paulo: Brasiliense, 1986, 149p., p.73.

${ }^{90}$ Nos anos 50, ver: CRUZ, O. R. Origens da revolução no teatro brasileiro. Brasiliense, São Paulo, n.8, p.106-22, nov./dez. 1956, p.120; e, quanto à peça Eles não usam black-tie: PINTO, P. F. A. Eles não usam “black-tie”, peça de Gianfrancesco Guarnieri. Brasiliense, São Paulo, n.16, p.179-82, mar./abr. 1957, p.182. Nos anos 60, sobre o movimento nacionalista brasileiro: CHADE, C. A autocrítica do movimento nacionalista brasileiro. Brasiliense, São Paulo, n.32, p.88-91, nov./dez. 1960, p.90; quanto ao Cinema Novo e ao filme Barravento: BERNARDET, J. C. "Barravento" e o recente cinema brasileiro. Brasiliense, São Paulo, n.44, p.35-7, nov./dez. 1962, p.136-7; quanto ao Cinema Novo por Claudio Mello e Souza, ver: FARIA, O. de. "Pôrto das Caixas e o Cinema Nôvo". Cadernos Brasileiros, v.5, n.2, p.77-83, mar./abr. 1963, p.80; e, quanto ao livro Cultura posta em questão, VALLADARES, C. Uma questão de cultura. Cadernos Brasileiros, v.7, n.4, p.83-8, jul./ago. 1965, p.86. Nos anos 70, sobre o cinema brasileiro produzido após a Segunda Guerra Mundial, ver: EMÍlIO, P. Cinema: trajetória no subdesenvolvido. Argumento, Rio de Janeiro, n.1, p.55-67, out. 1973, p.61. Nos anos 80, sobre o ISEB, consultar: TOLEDO, C. N. de. ISEB: Fábrica de ideologias. 2.ed. São Paulo: Ática, 1982, 195p., (Ensaios, 28), p.216; quanto ao CPC, ver: HOLLANDA, op. cit. e CHAUÍ, op. cit.; na coleção Cadernos do povo brasileiro: CHAUI, op. cit., p.84; e, nos volumes extras de Violão de rua (da coleção Cadernos do povo brasileiro), consultar: HOLLANDA, op. cit.

${ }^{91}$ ORTIZ, Cultura brasileira..., p.73.

${ }^{92}$ PAIANO, op. cit., p.76.

${ }^{93}$ MERQUIOR, op. cit., p.14.

${ }^{94}$ Particularmente, entre os intelectuais brasileiros da época, é possível perceber claros vestígios do texto A obra de arte na era de sua reprodutibilidade técnica. In: BENJAMIN, W. 
Magia e técnica, arte e política: ensaios sobre literatura e história da cultura. Trad. Sergio Paulo Rouanet. 5.ed. São Paulo: Brasiliense, 1993, 255p., p.165-96.

${ }^{95}$ CHAUÍ, op. cit., p.91.

${ }^{96}$ ORTIZ, Moderna tradição...

${ }^{97}$ MERQUIOR, op. cit., p.16.

${ }^{98}$ Ibidem, p. 17.

${ }^{99}$ Ibidem.

${ }^{100}$ Apud REIS, op. cit., p.79.

${ }^{101}$ MARTINS, op. cit., p.131.

${ }^{102}$ GULLAR, Cultura posta..., p.1.

${ }^{103}$ CHAVES NETO, E. Centro Popular de Cultura. Brasiliense, São Paulo, n.42, p.141-2, jul./ago. 1962, p.142.

${ }^{104}$ ORTIZ, Moderna tradição..., p.109-10.

${ }^{105}$ GULLAR, Cultura posta..., p.4.

${ }^{106}$ Ibidem.

${ }^{107}$ Ibidem, p.5, grifo nosso.

${ }^{108}$ Ibidem, p.9.

${ }^{109}$ Ibidem, p. 10.

${ }^{110}$ Ibidem, p.6-7.

${ }^{111}$ PEIXOTO, op. cit., p.95-6.

${ }^{112}$ GULLAR, Cultura posta..., p.19.

${ }^{113}$ Ibidem, p.24.

${ }^{114}$ Ibidem, p.1.

${ }^{115}$ VALLADARES, op. cit., p.83-8.

${ }^{116}$ GULLAR, F. Sim, uma questão de cultura. Cadernos Brasileiros, v.7, n.5, p.106-8, set./out. 1965.

${ }^{117}$ VALLADARES, op. cit., p.88.

${ }^{118}$ CORBISIER, op. cit., p.53. No parágrafo seguinte continua Corbisier, "ao falar na formação da cultura brasileira, portanto, queremos aludir à formação histórica do povo brasileiro". Ibidem, p.54.

${ }^{119}$ GULLAR, Sim, uma questão..., p.106. 
Miliandre Garcia

${ }^{120}$ GULLAR, Cultura posta..., p.4.

${ }^{121}$ GULLAR, Sim, uma questão..., p.107-8.

${ }^{122}$ IANNI, op. cit., p.8.

${ }^{123}$ CANDIDO, A. Radicalismos. Estudos Avançados, n.8, p.4-18, jan. 1988. p.7.

${ }^{124}$ Ibidem, p.5.

${ }^{125}$ Ibidem.

${ }^{126}$ Ibidem, p.6.

${ }^{127}$ Ibidem, p.9.

Artigo recebido em 3/2004. Aprovado em 5/2004 